\title{
STRUCTURE STUDIES ON THE AK7-SiC COMPOSITE AFTER MACHINING
}

\author{
ANALIZA STRUKTURY KOMPOZYTU TYPU AK7-SiC \\ PO OBRÓBCE UBYTKOWEJ
}

\author{
Małgorzata KAROLUS ${ }^{1}$, Jolanta CYBOROŃ ${ }^{1}$, Piotr PUTYRA ${ }^{1}$, \\ Maciej DYZIA ${ }^{2}$, Wiktoria RATUSZEK ${ }^{1}$
}

Abstract: The paper presents results of the structural studies on the composites of alumina matrix after machining processes. There were used two different methods: Electrical Discharge Machining (EDM) and Abrasive Water Jet (AWJ). The phase composition of the composite was carried out by X-ray diffraction (XRD). In order to investigate the heterogeneity of the material there were conducted additional measurements using the Grazing Incident X-ray Diffraction (GIXD) for angles of $1^{\circ}, 3^{\circ}, 5^{\circ}, 9^{\circ}$ and $12^{\circ}$. Residual stresses were determined based on the $\sin ^{2} \psi$ and grazing $\left(g\right.$ - $\left.\sin ^{2} \psi\right)$ methods for the main components of the composite alumina and silicon carbide. Analysis of the diffraction patterns performed for different X-ray penetration depths, showed that the tested material was inhomogeneous. Furthermore, depending on the treatment method (EDM or AWJ), the tested materials were shown the differences, both in the phase composition and the residual stresses values, as well.

Keywords: composite of alumina matrix, structural study, X-ray diffraction, GIXD, residual stress, Rietveld refinement

Streszczenie: W pracy przedstawiono wyniki badań strukturalnych stopów z układu AK7$10 \%$ obj. SiC, po procesie obróbki ubytkowej $\mathrm{z}$ wykorzystaniem dwóch metod: elektroerozyjnej i wodnościernej. Badania składu fazowego oraz jego zmian przeprowadzono metoda dyfrakcji rentgenowskiej (XRD) w geometrii Bragga-Brentano. W celu zbadania niejednorodności materiału przeprowadzono dodatkowe pomiary $\mathrm{w}$ geometrii stałego kata padania (SKP - Grazing Incident X-ray Diffraction) dla kąów padania promieniowania rentgenowskiego: $1^{\circ}, 3^{\circ}, 5^{\circ}, 9^{\circ}, 12^{\circ}$. Przeprowadzono pomiary naprężeń własnych dla głównych składników stopów, tj. Al i SiC, które wyznaczono w oparciu o metodę g-sin $2 \psi$. Analiza dyfraktogramów wykonanych przy różnych głębokościach wnikania promieniowania rentgenowskiego wykazała, iż badany materiał kompozytowy jest wielofazowy

\footnotetext{
${ }^{1}$ Centre for Materials Research and Sintering Technology, The Institute of Advanced Manufacturing Technology, Wrocławska 37a, 30-011 Cracow, Poland

${ }^{2}$ Silesian University of Technology, Faculty of Materials Engineering and Metallurgy, Krasińskiego 8, 40-019

Katowice, Poland
} 
i niejednorodny. Ponadto, w zależności od zastosowanej metody obróbki badanych materiałów (EDM i obróbka wodnościerna), wystąpiły różnice, zarówno w składzie fazowym, jak i w wielkościach wyliczonych naprężeń własnych.

Stowa kluczowe: kompozyt o osnowie tlenku glinu, analiza struktury, dyfrakcja rentgenowska, geometria stałego kąta padania SKP, naprężenia szczątkowe, metoda Rietvelda

\section{INTRODUCTION}

Aluminum-silicon cast alloy matrix composites are a group of materials characterized by a series of physical and mechanical properties for example: high strength, high stiffness and light weight [1] that enable their use in modern engineering designs. As an example, it may provide materials used for such components like: machine parts (bearings, gears) or internal combustion engines (pistons, crankshafts) [2].

In addition, reinforcement aluminum matrix ceramic particles such as $\mathrm{SiC}$, makes it possible to improve its strength and resistance to wear.

The differences in physical and mechanical properties of alumina and ceramic addition in this composite may make, in the place of their connection, a residual stresses, which directly influence on their strength. On the level and distribution of this stresses the biggest impact have got the difference in thermal expansion coefficients between ceramics and metal. The high magnitude of tensile stress ceramic phase related to high hardness and low fracture toughness can lead to the destruction of the bonds between components. Choosing the proper way of the manufacturing and machining these composites substantially affect to the final properties. Furthermore, the waste machining needed for obtaining these material generates a residual stress. The knowledge of the influence on the level and distribution of stresses in the metalceramic composites gives great potential in shaping the alloy structure, and thereby reducing their adverse effect, thus it is possible to increase the strength and reliability of the obtained materials.

The main purpose of this paper was to determine the effects of different methods of machining, mainly Electrical Discharge Machining (EDM) and Abrasive Water Jet (AWJ) on the structure and the residual stresses in the composite material type AK7-10\% vol. SiC.

\section{THE RESEARCH MATERIAL}

As the tested material metal casting alloy type AK7 (AlSi7Mg) reinforced with SiC particles was choosen. Composite was obtained by the stir casting (suspension) method from AlSi7Mg0,3 alloy in Zlotecki Company (Żelechlin, Poland). These material was melted in temperature $720^{\circ} \mathrm{C}$. After that these material was subjected to a refining process in the flow of argon with $\mathrm{v}=2 \mathrm{l} / \mathrm{h}$. Modification of the chemical composition of the alloy matrix was accomplished using a AlMg25 and AlSr additives. The volume fraction of the reinforcing SiC phase was $10 \%$. Sample for presented studies was cutted from extruder piston (Fig. 1). For the machining these composite used two methods: Electrical Discharge Machining (EDM) and Abrasive Water Jet (AWJ). Electrical Discharge Machining was used for the treatment of objects which was made of materials whose electrical conductivity is higher than $0.01 \mathrm{~S} / \mathrm{cm}$ [3]. EDM involves the removal of material from the work piece as a result of electrical charges occurring between the material work piece and the working electrode, which are submerged in 
a dielectric liquid. In the Abrasive Water Jet machining the principle of formation of the stream involved using water to accelerate the abrasive grains.
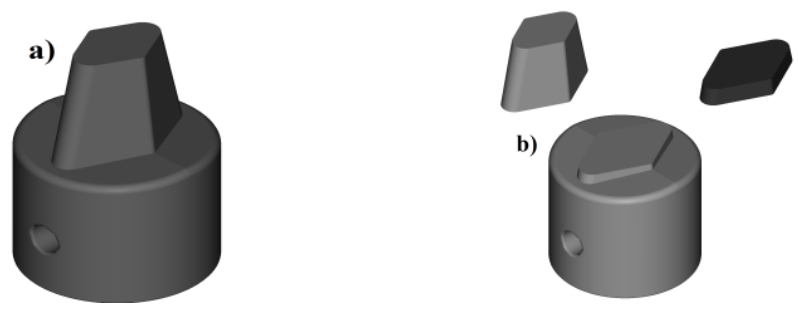

Figure 1. a) The casting piston, b) tested material

\section{RESULTS}

\subsection{X-RAY DIFFRACTION MEASUREMENTS (XRD)}

The X-ray diffraction patterns were performed by using the PANalitycal Empyrean diffractometer with the copper radiation $\left(\lambda_{\mathrm{Cu}}=1.5406 \AA\right)$. The phase analysis was done using the ICDD (PDF-4+ 2013) files. The quantitative phase analysis of studied material was carried out on the Rietveld refinement - using the HighScore PANalytical software [4,5] (Tables 1 and 2). The stress measurements were performed by using the Siemens D 500 diffractometer with the cooper radiation $\left(\lambda_{\mathrm{Cu}}=1.5406 \AA\right)(\mathrm{AGH}-$ University of Science and Technology Cracow, Poland). The calculation of the residual stress values were obtained by using the $\sin ^{2} \psi$ and $g-\sin ^{2} \psi$ methods [6,7].

In order to investigate the heterogeneity of the material, the measurements were performed on different measuring geometries (BB and GIXD), using different orientations of the samples to the direction of the radiation beam.

Moreover, for investigation of the heterogeneity within the one layer, the comparative measurements were performed for the entire test surface ("fixed" slits) and for narrow areas (,automatic" slits) - parallel and perpendicular to the primary beam - called the "long diagonal" and "short diagonal", respectively (Fig. 2). Such measurements were carried out for surfaces obtained after Electrical Discharge Machining and Abrasive Water Jet treatment, as well.
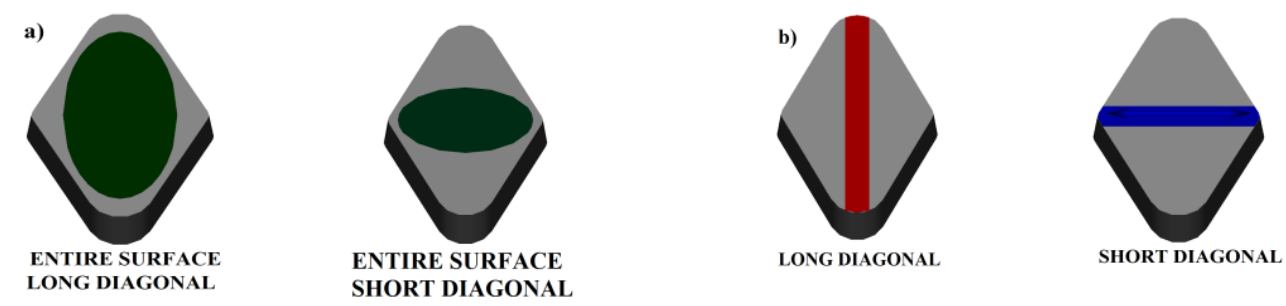

Figure 2. Testing areas: a) entire surface ("fixed" slits), b) narrow areas (,,automatic” slits) - parallel and perpendicular to the primary beam - called the "long diagonal" and "short diagonal" 
The results of the phase analysis of the composites after two ways of treatment (EDM and AWJ) - measured in BB and GIXD geometries, were presented in the Tables 1 and 2 and Figures 3 and 4.

Table 1. Qualitative and quantitative phase analyses of the AK7-SiC composite after Electrical Discharge Machining treatment

\begin{tabular}{|c|c|c|c|c|c|c|}
\hline \multirow{2}{*}{$\begin{array}{c}\text { EDM } \\
\text { method }\end{array}$} & \multirow{2}{*}{$\begin{array}{c}\text { Phase } \\
\text { composition }\end{array}$} & Space group & \multicolumn{2}{|c|}{ Long diagonal } & \multicolumn{2}{|c|}{ Short diagonal } \\
\cline { 4 - 7 } & & $\begin{array}{c}\text { narrow } \\
\text { areas }\end{array}$ & $\begin{array}{c}\text { entire } \\
\text { surface }\end{array}$ & $\begin{array}{c}\text { narrow } \\
\text { areas }\end{array}$ & $\begin{array}{c}\text { entire } \\
\text { surface }\end{array}$ \\
\hline \multirow{3}{*}{$\begin{array}{c}\mathrm{AK} 7- \\
\mathrm{SiC}\end{array}$} & $\mathrm{Al}$ & $\mathrm{Fm}-3 \mathrm{~m}$ & 84 & 65 & 66 & 61 \\
\cline { 2 - 7 } & $\mathrm{SiC}-6 \mathrm{H}$ & $\mathrm{P} 63 \mathrm{mc}$ & 9 & 21 & 24 & 25 \\
\cline { 2 - 7 } & $\mathrm{SiC}-4 \mathrm{H}$ & $\mathrm{P} 63 \mathrm{mc}$ & 4 & 10 & 8 & 8 \\
\cline { 2 - 7 } & $\mathrm{Si}$ & $\mathrm{Fd}-3 \mathrm{~m}$ & 1 & 2 & 2 & 3 \\
\cline { 2 - 7 } & $\begin{array}{c}\mathrm{SiC}- \\
\text { rhombohedral }\end{array}$ & $\mathrm{R} 3 \mathrm{~m}$ & 2 & 2 & - & 3 \\
\hline
\end{tabular}

Table 2. Qualitative and quantitative phase analyses of the composite AK7-SiC after Abrasive Water Jet treatment

\begin{tabular}{|c|c|c|c|c|c|c|}
\hline \multirow{2}{*}{$\begin{array}{c}\text { AWJ } \\
\text { method }\end{array}$} & \multirow{2}{*}{$\begin{array}{c}\text { Phase } \\
\text { composition }\end{array}$} & Space group & \multicolumn{2}{|c|}{ Long diagonal } & \multicolumn{2}{|c|}{ Short diagonal } \\
\cline { 4 - 7 } & & narrow & $\begin{array}{c}\text { entire } \\
\text { surface }\end{array}$ & $\begin{array}{c}\text { narrow } \\
\text { areas }\end{array}$ & $\begin{array}{c}\text { entire } \\
\text { surface }\end{array}$ \\
\hline \multirow{3}{*}{$\begin{array}{c}\text { AK7- } \\
\mathrm{SiC}\end{array}$} & $\mathrm{Al}$ & $\mathrm{Fm}-3 \mathrm{~m}$ & 81 & 72 & 69 & 71 \\
\cline { 2 - 7 } & $\mathrm{SiC}-6 \mathrm{H}$ & $\mathrm{P} 63 \mathrm{mc}$ & 13 & 20 & 22 & 20 \\
\cline { 2 - 7 } & $\mathrm{SiC}-4 \mathrm{H}$ & $\mathrm{P} 63 \mathrm{mc}$ & 5 & 6 & 7 & 7 \\
\hline
\end{tabular}

Based on the Tables 1-2 and Figures 3-4, we could determine the character of structure of the obtained materials. Phase distribution in the composite was non homogenous, both - within one surface layer and versus the penetration depth. The phase analysis results have also shown that the quantity of the alumina phase is higher on the edges of the sample ("long diagonal"). 


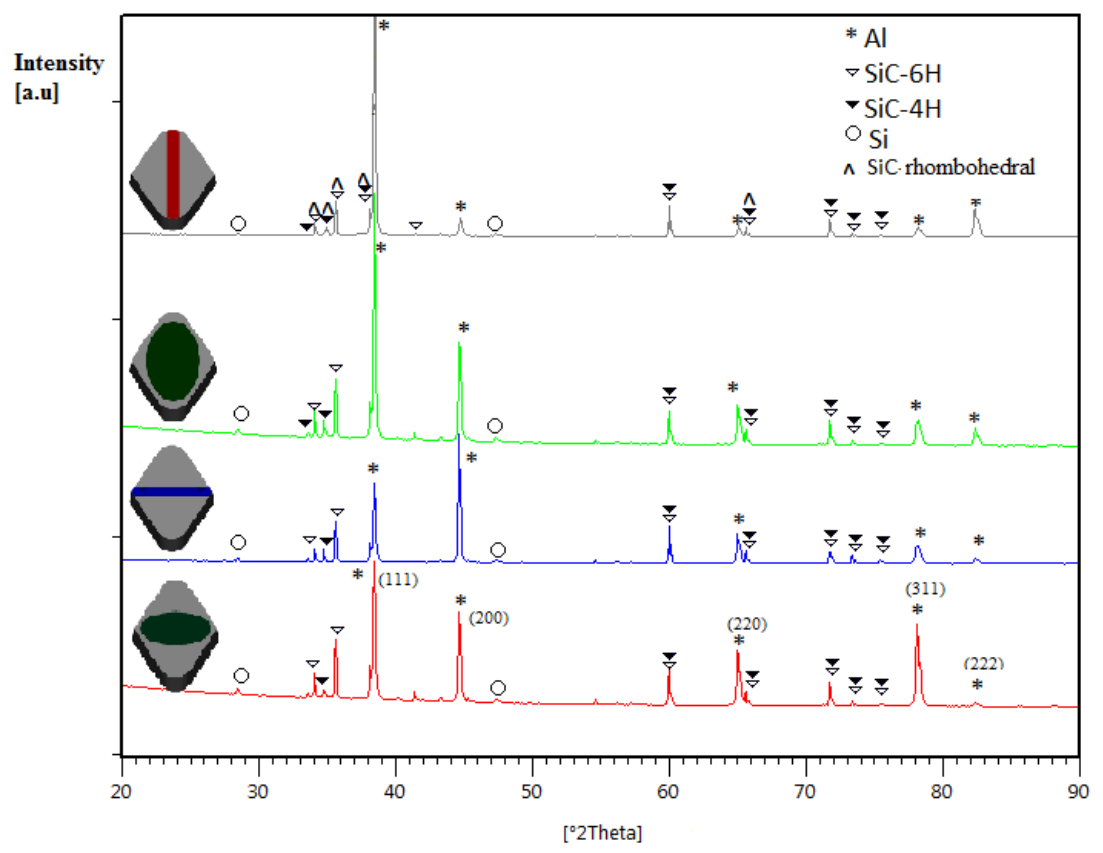

Figure 3a. XRD patterns obtained for the composite after EDM treatment, for different sample positions ("short" and "long" diagonals)

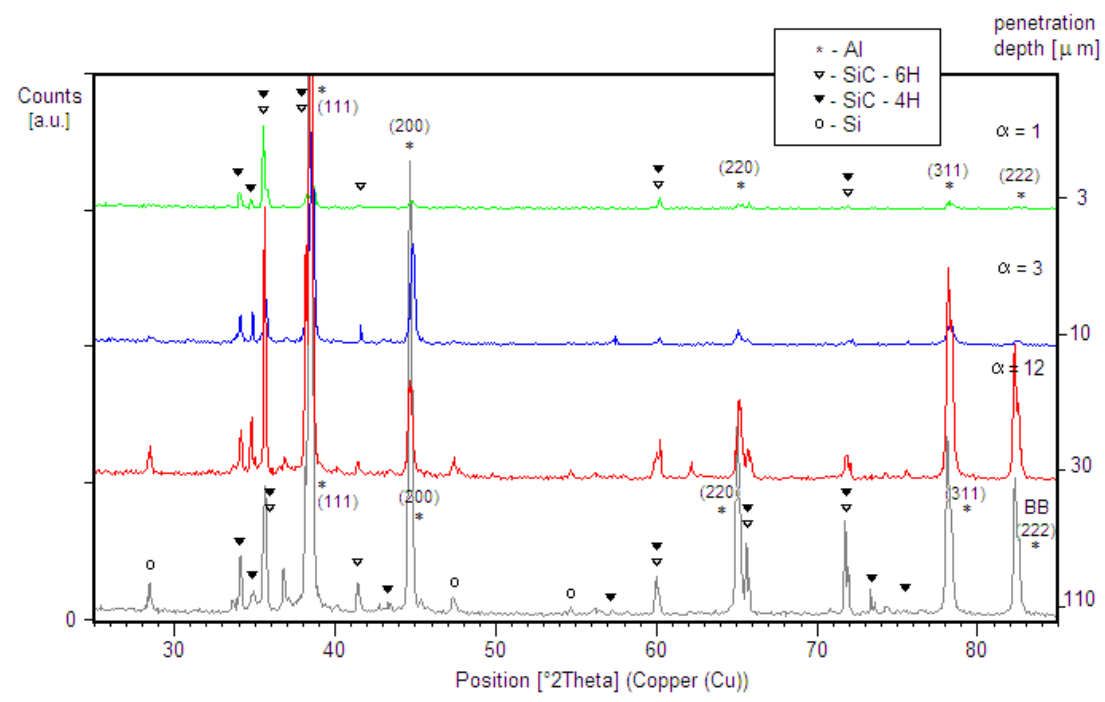

Figure 3b. XRD patterns obtained for the composite after EDM treatment, for different layers of the sample (GIXD) 


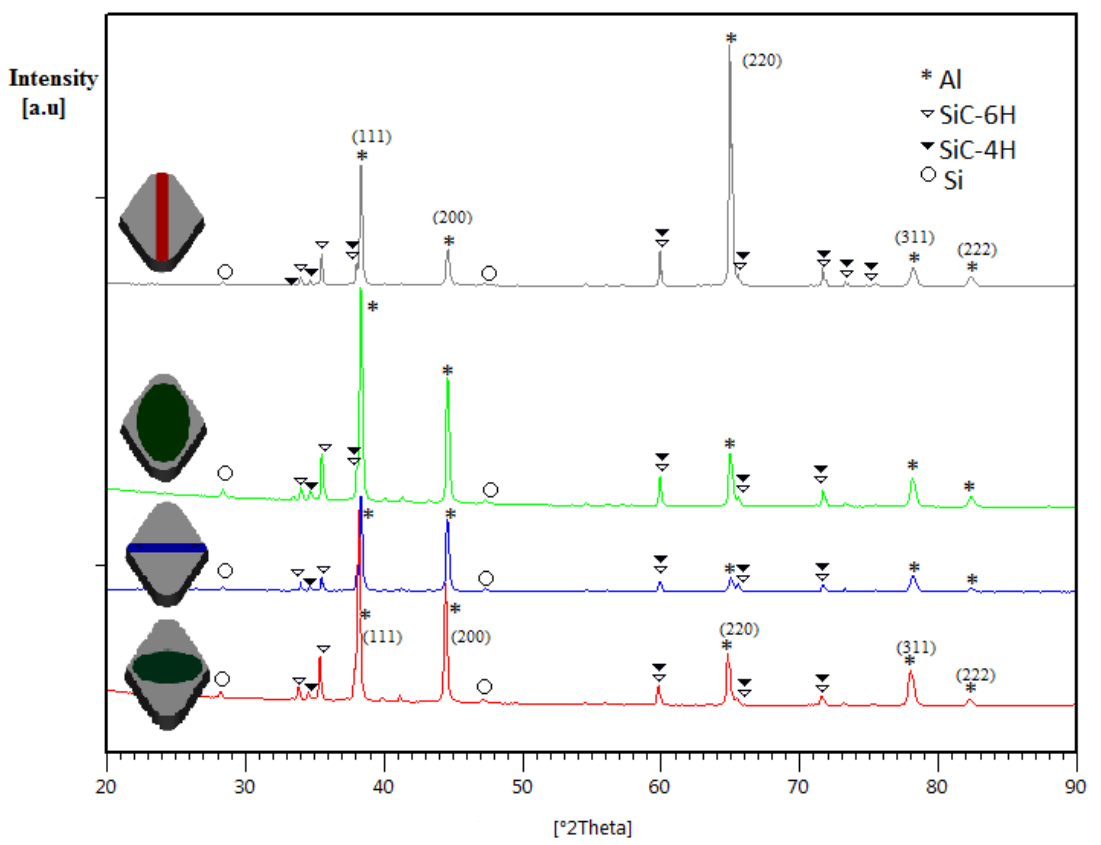

Figure 4a. XRD patterns obtained for the composite after AWJ treatment, for different sample positions ("short" and "long" diagonals)

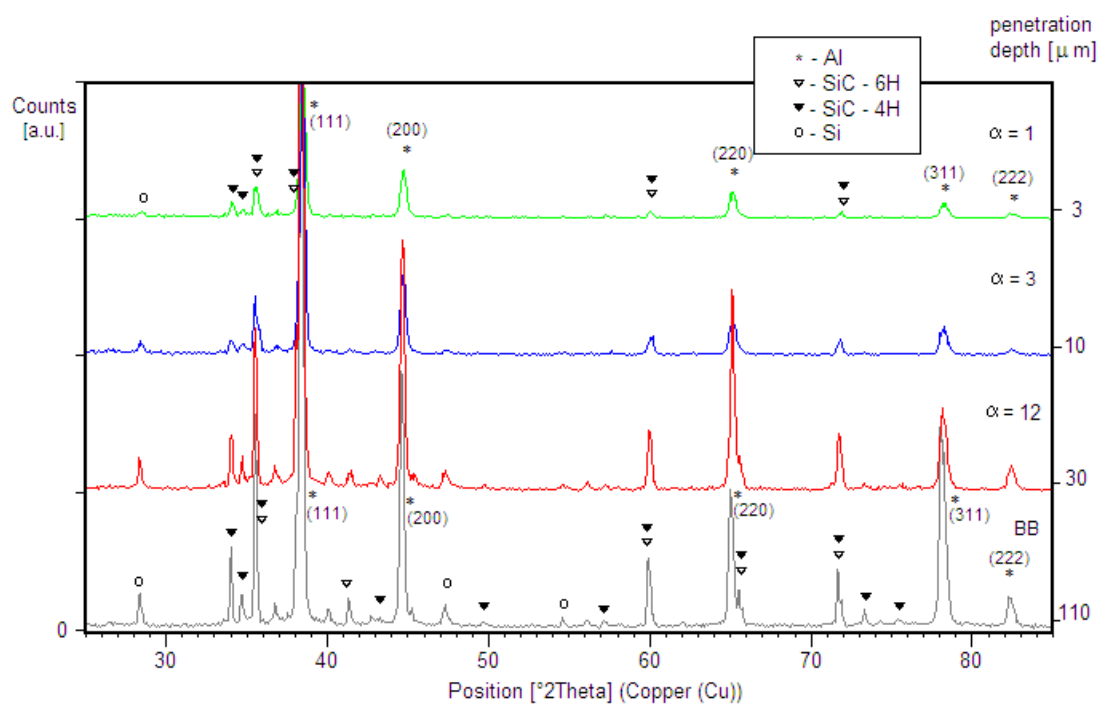

Figure 4b. XRD patterns obtained for the composite after AWJ treatment, for different layers of the sample (GIXD) 


\subsection{THE EFFECTIVE X-RAY PENETRATION DEPTH ANALYSIS}

The studies on the material heterogeneity were based on the analysis of the diffraction patterns obtained by the Grazing Incident X-ray Diffraction geometry (GIXD). According to the equations (1) and (2), effective penetration depth (Z) of X-ray [6,7] - for the different phases and different incidence beam angles - were calculated (Table 3, Fig. 6-8):

$$
\begin{aligned}
& Z_{B B}=\frac{-\ln \left(1-G_{\chi}\right)}{2 \mu} \sin \theta \\
& Z_{G I X D}=\frac{-\ln \left(1-G_{\chi}\right)}{\mu\left[\frac{1}{\sin \alpha}+\frac{1}{\sin (2 \theta-\alpha)}\right]}
\end{aligned}
$$

where:

$Z_{\mathrm{BB}}$ - effective penetration depth in Bragg-Brentano geometry

$\mathrm{Z}_{\mathrm{GIXD}}$ - effective penetration depth in Grazing Incident X-ray Diffraction geometry

$\mu$ - linear absorption coefficient

$\theta$ - diffraction angle

$\mathrm{Gx}$ - constant factor

$\alpha$ - angle of incident beam.

Table 3. Penetration depth of X-rays in BB and GIXD geometries for different phases in the AK7-SiC composite

\begin{tabular}{|c|c|c|c|}
\hline & \multicolumn{3}{|c|}{$\mu-$ linear absorption coefficient $\left[\mathrm{cm}^{-1}\right]$} \\
\hline Diffraction geometry & $\begin{array}{c}\text { SiC-6H } \\
\mu=151.31\end{array}$ & $\begin{array}{c}\mathrm{A} 1 \\
\mu=35.62\end{array}$ & $\begin{array}{c}\mathrm{Si} \\
\mu=152.2\end{array}$ \\
\hline & \multicolumn{2}{|c|}{ Penetration depth of X-rays $[\mu \mathrm{m}]$} \\
\hline $\mathrm{BB}$ & $>8(8-100)$ & $>9(9-110)$ & $>8$ \\
\hline GIXD, $\alpha=1^{\circ}$ & 3.35 & 3.75 & 3.35 \\
\hline GIXD, $\alpha=3^{\circ}$ & 9.51 & 10.67 & 9.51 \\
\hline GIXD,$\alpha=5^{\circ}$ & 15.01 & 16.85 & 15.01 \\
\hline GIXD, $\alpha=9^{\circ}$ & 24.13 & 27.08 & 24.13 \\
\hline GIXD, $\alpha=12^{\circ}$ & 29.57 & 32.99 & 29.4 \\
\hline
\end{tabular}




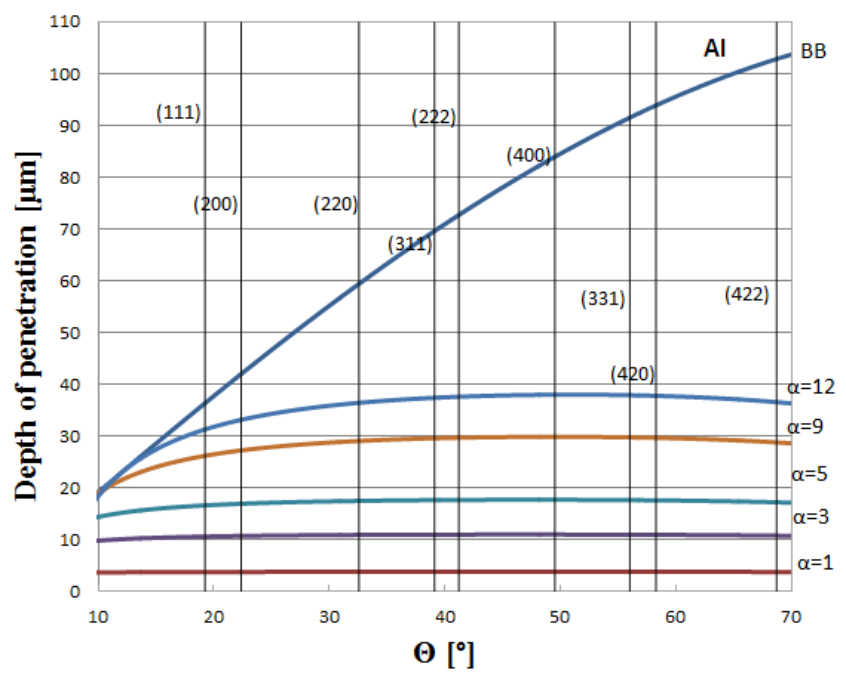

Figure 5. Penetration depth of X-rays for aluminum phase in BB and GIXD geometries, perpendicular lines represent diffraction lines (hkl) for aluminum

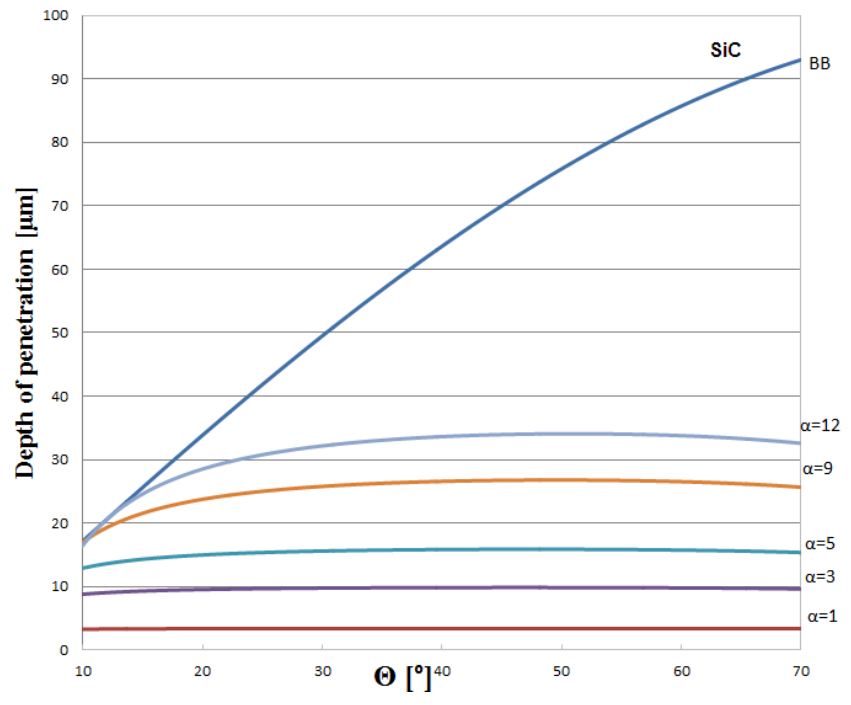

Figure 6. Penetration depth of X-rays for SiC phases in BB and GIXD geometries 


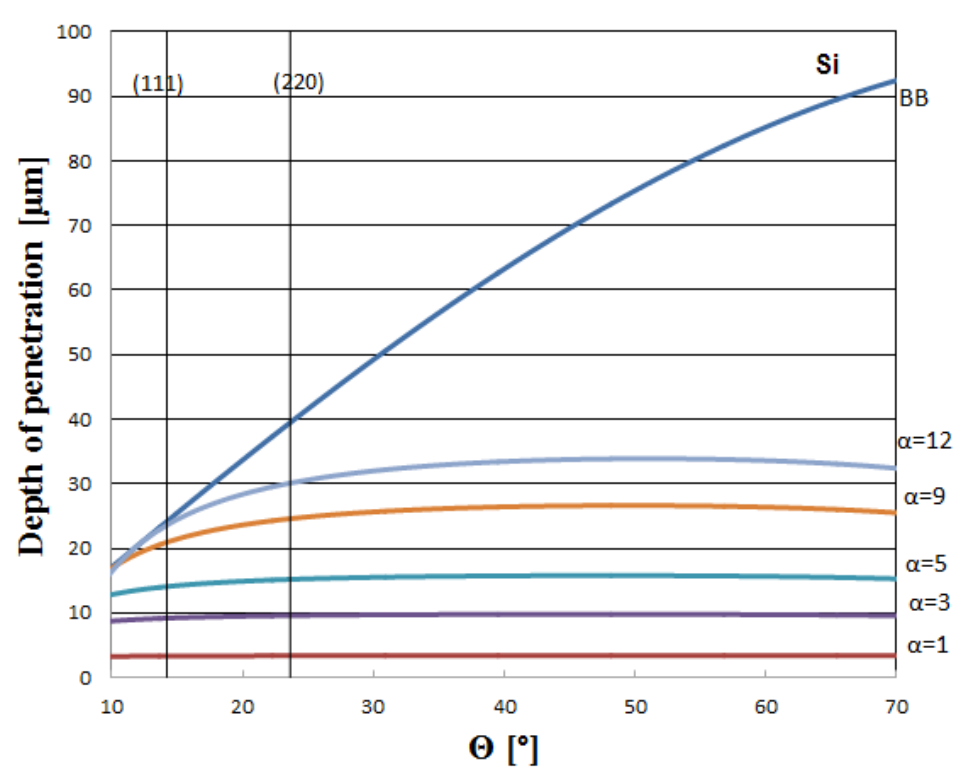

Figure 7. Penetration depth of X-rays for silicon phase in BB and GIXD geometries, perpendicular lines represent two strongest diffraction lines (hkl) for silicon

\subsection{STRESS DETERMINATION}

Due to the a heterogeneous structure of tested composite, the stress determination were performed by using the $\sin ^{2} \psi$ and $g-\sin ^{2} \psi$ methods, as well. The values of the Young's modulus $-E$ and Poisson coefficient $-v$ for $\mathrm{Al}$ and $\mathrm{SiC}$ phases, taken into account in residual stress calculations, were presented in the Table 4.

Table 4. The values of Young's modulus - $E$ and Poisson coefficients - $v$, for Al and SiC phases

\begin{tabular}{|c|c|c|}
\hline Phase & Young's modulus $-\mathrm{E}[\mathrm{GPa}]$ & Poisson coeficient $-v$ \\
\hline $\mathrm{Al}$ & 70.14 & 0.3499 \\
\hline $\mathrm{SiC}-6 \mathrm{H}$ & 455 & 0.1600 \\
\hline
\end{tabular}

Table 5. The values of the residual stresses - $\sigma[\mathrm{MPa}]$ for different layers of $\mathrm{Al}$ composite reinforced $\mathrm{SiC}$ particles after EDM treatment

\begin{tabular}{|c|c|c|c|c|}
\hline \multirow{2}{*}{ XRD geometry } & \multicolumn{4}{|c|}{ Residual stress - $\sigma[\mathrm{MPa}]$} \\
\cline { 2 - 5 } & \multicolumn{3}{|c|}{ SiC-6H } & \multicolumn{2}{c|}{\begin{tabular}{c}
$\mathrm{Al}$ \\
\cline { 2 - 5 }
\end{tabular}} & $\begin{array}{c}\text { Short } \\
\text { diagonal }\end{array}$ & $\begin{array}{c}\text { Long } \\
\text { diagonal }\end{array}$ & $\begin{array}{c}\text { Short } \\
\text { diagonal }\end{array}$ & $\begin{array}{c}\text { Long } \\
\text { diagonal }\end{array}$ \\
\hline B-B & -530.8 & -212.2 & -69.9 & -65.8 \\
\hline GIXD, $\alpha=1^{\circ}$ & 819.5 & -620.7 & 36.6 & -140.3 \\
\hline GIXD, $\alpha=3^{\circ}$ & -53.7 & 570 & -77.5 & 88.2 \\
\hline
\end{tabular}


Table 6. The values of the residual stresses $-\sigma[\mathrm{MPa}]$ for different layers of $\mathrm{Al}$ composite reinforced $\mathrm{SiC}$ particles after $\mathrm{AWJ}$ treatment

\begin{tabular}{|c|c|c|c|c|}
\hline & \multicolumn{4}{|c|}{ Residual stress - $\sigma[\mathrm{MPa}]$} \\
\hline \multirow{2}{*}{ XRD geometry } & \multicolumn{2}{|c|}{ SiC-6H } & \multicolumn{2}{c|}{ Al } \\
\cline { 2 - 5 } & $\begin{array}{c}\text { Short } \\
\text { diagonal }\end{array}$ & $\begin{array}{c}\text { Long } \\
\text { diagonal }\end{array}$ & $\begin{array}{c}\text { Short } \\
\text { diagonal }\end{array}$ & $\begin{array}{c}\text { Long } \\
\text { diagonal }\end{array}$ \\
\hline B-B & -1651.2 & -2632.7 & -201.2 & -336.9 \\
\hline GIXD, $\alpha=1^{\circ}$ & -328.6 & -1141.6 & -28.4 & -223.1 \\
\hline GIXD, $\alpha=3^{\circ}$ & -167.8 & -1697.5 & -53.6 & -224 \\
\hline
\end{tabular}

Contrary to conventional method of residual stress determination $\left(\sin ^{2} \psi\right)$, the values of the stress were analyzed by the grazing method $\left(g-\sin ^{2} \psi\right)$, as well. The obtained results (Tables 4 and 5) showed the big differences. It was associated with the significant gradient of stresses in the different layers of the composite. It is caused by the heterogeneity of the material.

\subsection{MICROSTRUCTURE OF THE COMPOSITE (SEM)}

The morphology of the tested materials after EDM and AWJ treatments, was studied by scanning electron microscope (SEM) (JEOL JSM-6460LV) equipped with energy dispersive spectroscopy (EDS INCA X-act Energy 350 Oxford Instruments.

Figure 8 presents SEM photomicrograph of the composite after the EDM process. We could observe a specific area (defined as "1"), which could be connected with mostly due to thermal processes and phase transitions [2] mainly melting and evaporation from the surface of the material. In Figure 9, after the AWJ treatment, there are the specific surface - long, distinct scratches - connected to the AWJ process.

a)

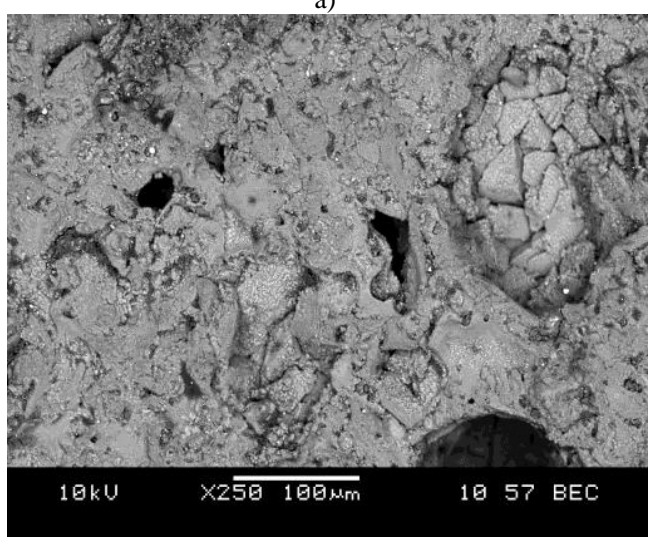

b)

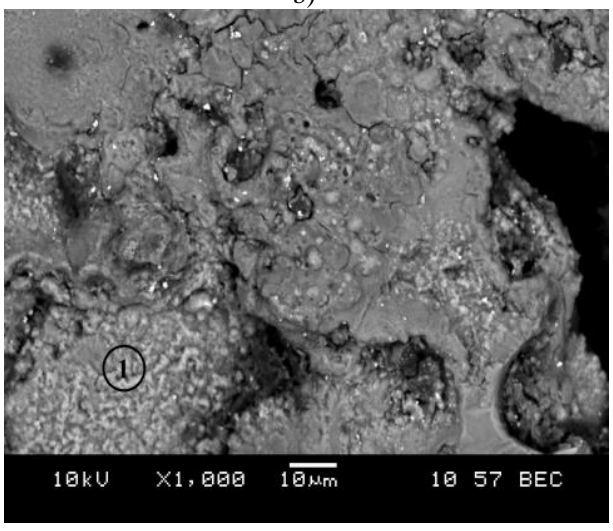

Figure 8. SEM image of AlSi-10\% vol. SiC composite after EDM treatment: a) mag. $x 250$ and b) mag. $x 1000$ 
a)

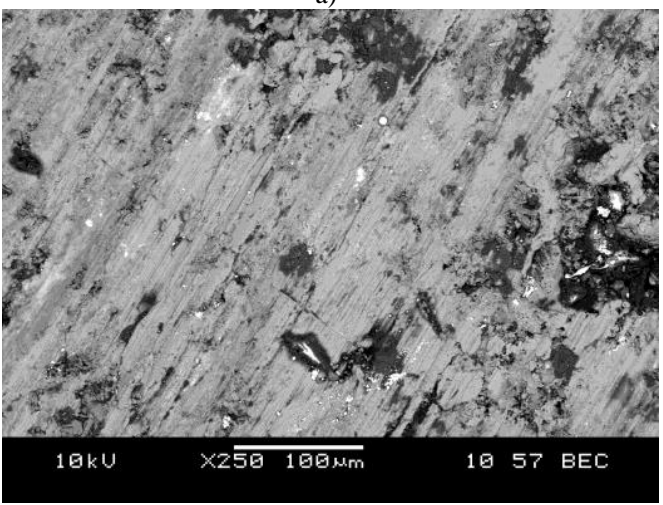

b)

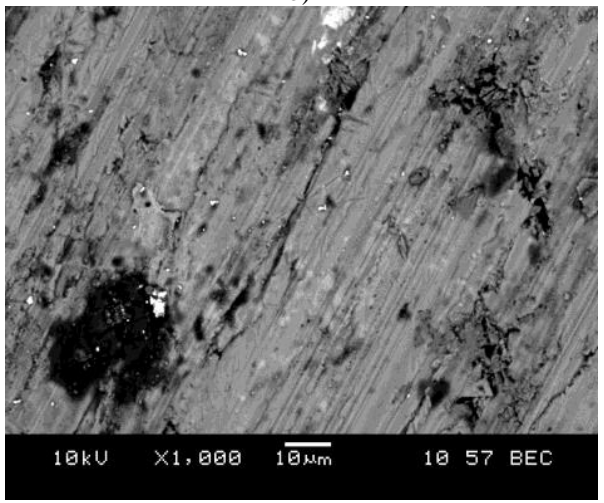

Figure 9. SEM image of AlSi-10\% vol. SiC composite after AWJ treatment: a) mag. x 250 and b) mag. x 1000

\section{CONCLUSIONS}

The stir casting (suspension) method produces non-homogenous and textured material. The composites AK7 with 10 vol.\% SiC addition has got an inhomogeneous structure within one layer of the surface and depending on the penetration depth, as well.

XRD analyses have shown the presence of the aluminum, silicon carbide ( $\mathrm{SiC} 6 \mathrm{H}, \mathrm{SiC} 4 \mathrm{H}, \mathrm{SiC}$ rhombohedral) and Si phases in the composite.

The studies have shown the influence of treatment methods (Electrical Discharge Machining and Abrasive Water Jet Treatment) on the residual stress and texture in the AK7 type composite.

\section{ACKNOWLEDGEMENTS}

This work was supported by the Applied Research Program: “Opracowanie składu fazowego kompozytów na bazie stopu AlSi pod kątem możliwości kształtowania powierzchni roboczych tłoków”, KOMPCAST, Nr PBS1/B6/13/2013.

\section{REFERENCES}

[1] SOBCZAK J., WOJCIECHOWSKI S., Wspótczesne tendencje praktycznego zastosowania kompozytów metalowych: Kompozyty, Vol.2, 2002, s. 25-37.

[2] LLOYD DJ, LAGACE H, McLEODA, MORRIS P.L., Microstructural aspects of aluminum silicon-carbide particulate composites produced by a casting method: Mater Sci. Eng. A, 107, 1989, 73-80.

[3] KUNIEDA M., LAUWERS B., RAJURKAR K.P., SCHUMACHER B.M., Advancing EDM through Fundamental Insight into the Process: Cirp Annals - Manufactorin Technology, Volume 54, Issue 2, 2005, 6487.

[4] YOUNG R.A., The Rietveld method, Oxford University Press, 1993.

[5] McCUSKER LB., Von DREELE R.B., COX D.E., LOUER D., SCARDI P., Rietveld refinement guidelines: J.Appl. Crystallogr., 32, 1999, 36-50.

[6] CULLITY B.D., Elements of X-ray diffraction, Prentice-Hall Inc., New Jersey 2001.

[7] SKRZYPEK S.J., Nowe możliwości pomiaru makronaprężé́ własnych materiałów przy zastosowaniu dyfrakcji promieniowania $X w$ geometrii statego kata padania, Uczelniane Wydawnictwa Naukowo-Dydaktyczne, Kraków 2002. 